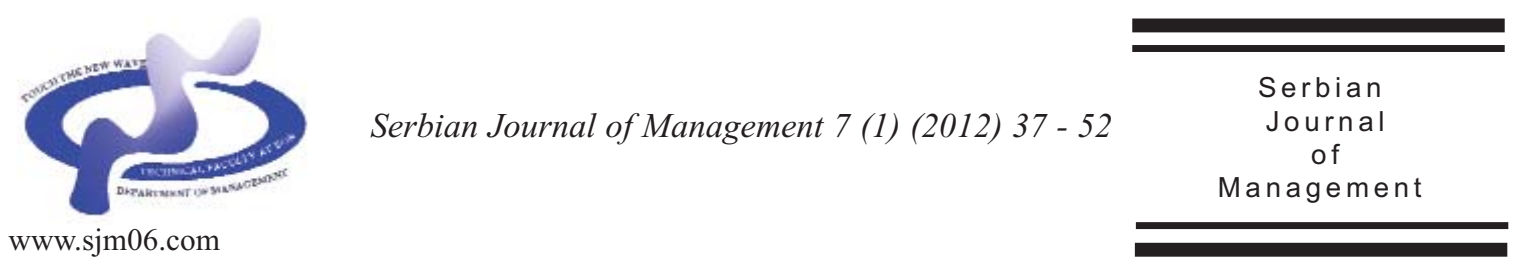

\title{
ANALYSIS OF BUSINESS ENVIRONMENT USING THE MULTI-CRITERIA APPROACH - CASE OF BALKAN'S TRANSITION ECONOMIES
}

\author{
Saša Obradovića ${ }^{\text {, Aleksandra Fedajev }}{ }^{b^{*}}$ and Đorđe Nikolićb \\ ${ }^{a}$ University of Kragujevac, Faculty of Economics in Kragujevac, \\ Đure Pucara Starog 3, Kragujevac, Serbia \\ $b$ University of Belgrade, Technical Faculty in Bor, Vojske Jugoslavije 12, Bor, Serbia
}

(Received 1 September 2011; accepted 17 January 2012)

\begin{abstract}
Due to the lack of their own financial resources, attracting the foreign direct investment (FDI) is the main prerequisite for transitional economies in order to increase production and employment, so that they can ensure the long term sustainable economic growth. In addition, the foreign direct investment is an important instrument for the economy restructuring, based on market principles. However, achieving this goal is not simple at all. In order to attract foreign investors, it is necessary to create a favorable business environment in transition countries, which requires a number of economic, institutional, political and other reforms. The aim of this paper is to point out the main factors attracting foreign direct investment and, by using the multi-criteria approach, to rank the Balkan's transition economies depending on the preferences of investors taking into account certain components of the business environment.
\end{abstract}

Keywords: Foreign direct investment, business environment, multi-criteria analysis, the PROMETHEE method

\section{INTRODUCTION}

One of the most important forms of production factors flows is the international capital flow. The globalization of financial flows has created the conditions for the rational allocation of capital, enabling investors to invest their capital in countries where they can achieve higher profit than in the home country. In other words, investors from developed countries invest available capital in those local projects where the marginal return on capital in the country is higher than the marginal return on capital

*Corresponding author: afedajev@tf.bor.ac.rs

DOI: 10.5937/sjm 12010370 
invested in projects abroad. When realize all these projects, foreign investors continue seeking alternative investment opportunities across national borders.

On the other hand, the transition countries are forced to fund the missing accumulation from foreign sources, as they have the low level of Gross Domestic Product (GDP) per capita and, accordingly, the low national savings rate. In that sense, the foreign direct investment is the most convenient and cheapest source of financing the economic growth in transition countries, because these foreign investors do not bring only capital, but also modern technology and know-how as well.

The South Eastern European (SEE) countries have not completed the process of transition yet. All of them are at different distances from achieving this target, depending on when and how seriously they have understood the importance of this process. Until 1990s, they were beyond the international capital flows. I amely, given the character and ideology of the centrally planned system that existed in these countries, Foreign Direct Investment (FDI) was taken as the investor's claim from capitalist economies to exploit local labor, natural resources and mineral resources, transferring surplus value abroad. The attitude referring to the importance and effects of foreign direct investment, has been changed as soon as the existing economic system has shown many weaknesses and the transition of these economies to market economies has become inevitable.

For a long time, there was the feeling in these countries that foreign capital will certainly come, regardless the business environment characteristics. However, the elapsed time has shown that "a healthy foreign capital" flows in the countries that offer a higher profit rate and a lower level of risk (Beslać, 2006). In addition to achieving higher profits, as the main motive, foreign investors have a variety of other reasons for starting a business abroad, such as transferring their own technology, easy access to resources, access to new markets, expansion of production, overcoming the tariffs or other barriers. Achieving these goals is possible only if there are appropriate conditions for starting and conducting business activities in the given country or, in other words, if there is a favorable and stable business environment. Donor Committee for Enterprise Development (DCED) defines business environment as a complex of political, legal, institutional and regulatory conditions affecting business activities (Donor Committee for Enterprise Development, 2008). So containing many aspects, the business environment is a multidimensional phenomenon that has to be divided into components, in order to analyze their individual impact on the inflow of foreign direct investment.

In this sense, the aim of this paper is to identify the basic components of business environment, to quantify each of them and, on that basis, to rank the Balkan transition economies (net capital importers) depending on investor's preferences.

\section{LITERATURE REVIEW}

The allocation of FDI has arose the interest of many authors. The process of decision making on the allocation of capital itself has not been extensively analyzed, but the majority of papers were focused on the effects of FDI on the economic growth and development, the definition of the determinants of foreign direct investment, 
the quantification of the importance of each of them and, on this basis, the prediction of future inflows of foreign capital.

Most authors of these papers come from countries in transition, the countries that attempt to increase the inflow of foreign direct investment by the business environment reform. Bevan and Estrin (Bevan \& Estrin, 2004) stress the importance of prompt and efficient completion of the transition process and achieving the candidate status for EU membership. Buth and Milner (Buth \& Milner, 2008), in turn, argue that, besides other conditions, the arrangement with the General Agreement on Tariffs and Trade (GATT) and World Trade Organization (WTO) as well as preferential trade arrangements significantly affect the inflow of FDI. In addition to the membership in international regional and trade organizations, there are many socio political factors that play an important role in the decision making process of potential investors. The most often discussed factors are the educational system, tax incentives, the level of privatization, political stability, trade and tax system reform, labor market characteristics, macroeconomic stability, market liberalization, legal framework, corruption, infrastructure development and many other variables (Trevino et al., 2008; Bevan \& Estrin, 2004; Carstensen \& Toubal, 2004; Birsan \& Buiga, 2009). It can be concluded that authors from transition countries are primarily focused on the endogenous factors, trying to point out the importance of reforms to be implemented in order to attract as many foreign investors as possible.

Unlike to these papers, if we look at the factors of FDI from the point of view of the country of the recipient of capital, there are numerous studies that analyze factors determining FDI from the perspective of investors. One of them is Tatoglu and Glaister study (Tatoglu \& Glaister, 2010), based on the survey of 98 firms that have invested in Turkey. The analysis of the survey data point out that the most common motives for investment were the access to new markets and easy market entry. Similarly, the paper "Modeling Russian outward FDI" by Kalotay and Sulstarova (Kalotay \& Sulstarova, 2010) indicates the investment motives of Russian investors and their change over time. I amely, during 1990, large private Russian companies opened branches abroad in order to protect business from the instability of the domestic market, while nowdays state-owned companies invest abroad in order to preserve the value chain of their products. In addition, they concluded that the major determinants, influencing decisions of Russian investors, were the market size and the availability of natural resources.

A large number of studies explore the motives of FDI in the regional framework. They are focused on analyzing the key determinants of foreign investment in given country, located on the territory of some region, where countries in that region have quite similar characteristics of business environment. In this sense, Rasciute and Pentecost (Rasciute \& Pentecost, 2010) found that, in that case, the simultaneous effect of factors on firm, the industry and the country level determine decisions of investors. In such circumstances, foreign investors find out these countries to be perfect substitutes, and so that the synergy factors at all three levels affect the final decision making.

Hence, decisions about the location of FDI are based on a detailed analysis of numerous factors. The more factors are 
Table 1. Business environment factors

\begin{tabular}{|c|c|}
\hline CLASTER & I!IICATORS WITHI! CLASTERS \\
\hline $\begin{array}{l}\text { 1. Level of } \\
\text { privatization }\end{array}$ & $\begin{array}{l}\text { (1) Small-scale privatization ; (2) Large-scale privatization }{ }^{\mathrm{a}} \text {; (3) Enterprise } \\
\text { restructuring ; (4) Private sector share of GDP }\end{array}$ \\
\hline $\begin{array}{l}\text { 2. Efficiency and } \\
\text { size of good market }\end{array}$ & $\begin{array}{l}\text { (1) Price liberalization }{ }^{\mathrm{a}} \text {; (2) Trade \& Forex system }{ }^{\mathrm{a}} \text {; (3) Competition Policy }{ }^{\mathrm{a}} \text {; } \\
\text { (4) Gross domestic product per capita based on purchasing-power-parity } \\
(\mathrm{PPP})^{\mathrm{c}} \text {; (5) Population }{ }^{\mathrm{c}} \text {. }\end{array}$ \\
\hline $\begin{array}{l}\text { 3. Development of } \\
\text { financial market }\end{array}$ & $\begin{array}{l}\text { (1) Banking reform \& interest rate liberalization }{ }^{\mathrm{a}} ;(2) \text { Securities markets \& non- } \\
\text { bank financial institutions } \mathrm{s}^{\mathrm{a}} \text {; (4) Strength of legal rights index } \mathrm{d}^{\mathrm{d}} \text {; (5) Depth of } \\
\text { credit information index }^{\mathrm{d}} \text {; (6) Public registry coverage } \mathrm{d}^{\mathrm{d}} \text {; (7) Public registry } \\
\text { bureau coverage } \mathrm{e}^{\mathrm{d}} \text {. }\end{array}$ \\
\hline 4. Infrastructure & $\begin{array}{l}\text { (1) Overall infrastructure reform }{ }^{\mathrm{a}} \text {; (2) Telecommunications }{ }^{\mathrm{a}} \text {; (3) Railways } \mathrm{s}^{\mathrm{a}} \text {; } \\
\text { (4) Electric power } ; \text { (5) Roads }{ }^{\mathrm{a}} \text {. }\end{array}$ \\
\hline $\begin{array}{l}\text { 5. Macroeconomic } \\
\text { stability }\end{array}$ & $\begin{array}{l}\text { (1) Inflation }{ }^{c} ; \text { (2) Unemployment rate }{ }^{c} ;(3) \text { General government gross debt } \\
\text { (\% of GDP) })^{c} \text {. }\end{array}$ \\
\hline $\begin{array}{l}\text { 6. Starting a } \\
\text { business and } \\
\text { dealing with } \\
\text { construction } \\
\text { permits }\end{array}$ & $\begin{array}{l}\text { (1) Procedures (number })^{\mathrm{d}} ;(2) \text { Time }(\text { days })^{\mathrm{d}} ; \text {; } 3 \text { Cost }\left(\% \text { of income per capita) }{ }^{\mathrm{d}} \text {; }\right. \\
\left.\text { (4) Paid-in Min. Capital }(\% \text { of income per capita })^{\mathrm{d}} ;(5) \text { Procedures (number }\right)^{\text {; }} \text {; } \\
\text { (7) Time (days })^{\mathrm{d}} ; \text {; (8) Cost }(\% \text { of income per capita })^{\mathrm{d}} \text {. }\end{array}$ \\
\hline $\begin{array}{l}\text { 7. Registering } \\
\text { Property }\end{array}$ & (1) Procedures (number) ${ }^{\mathrm{d}}$; (2) Time (days) ${ }^{\mathrm{d}}$; (3) Cost (\% of property value) ${ }^{\mathrm{d}}$. \\
\hline $\begin{array}{l}\text { 8. Protecting } \\
\text { investors and } \\
\text { enforcing } \\
\text { contracts }\end{array}$ & $\begin{array}{l}\text { (1) Extent of disclosure index }{ }^{\mathrm{d}} ;(2) \text { Extent of director liability index }{ }^{\mathrm{d}} \text {; (3) Ease } \\
\text { of shareholder suits index } x^{\mathrm{d}} ;(4) \text { Strength of investor protection index } \\
\left.\text { (5) Procedures (number })^{\mathrm{d}} ; \text {; (6) Time (days }\right)^{\mathrm{d}} ;(7) \text { Cost }(\% \text { of claim })^{\mathrm{d}} \text {. }\end{array}$ \\
\hline 9. Paying taxes & $\begin{array}{l}\text { (1) Payments (number per year) }{ }^{\mathrm{d}} ;(2) \text { Time (hours per year) }{ }^{\mathrm{d}} ; \text { (3) Total tax rate } \\
(\% \text { profit })^{\mathrm{d}} .\end{array}$ \\
\hline $\begin{array}{l}\text { 10. Trading across } \\
\text { borders }\end{array}$ & $\begin{array}{l}\text { (1) Documents to export (number) })^{\mathrm{d}} \text {; (2) Time to export (days) }{ }^{\mathrm{d}} \text {; } \text {; (3) Cost to } \\
\text { export (US\$ per container) }{ }^{\mathrm{d}} \text {; (4) Documents to import (number) }{ }^{\mathrm{d}} \text {; (5) Time to } \\
\left.\text { import (days) }{ }^{\mathrm{d}} ;(6) \text { Cost to import (US\$ per container) }\right)^{\mathrm{d}} \text {. }\end{array}$ \\
\hline $\begin{array}{l}\text { 11. Closing a } \\
\text { business }\end{array}$ & $\begin{array}{l}\left.\text { (1) Recovery rate (cents on the dollar) }{ }^{\mathrm{d}} ;(2) \text { Time (years }\right)^{\mathrm{d}} ;(3) \text { Cost } \\
(\% \text { of estate })^{\mathrm{d}} \text {. }\end{array}$ \\
\hline $\begin{array}{l}\text { 12. Governance } \\
\text { indicators }\end{array}$ & $\begin{array}{l}\text { (1) Voice and accountability }{ }^{\mathrm{e}} \text {; (2) Political stability }{ }^{\mathrm{e}} \text {; (3) Government } \\
\text { effectiveness }{ }^{\text {e }} \text {; (4) Regulatory Quality }{ }^{\mathrm{e}} \text {; (5) Rule of Law } \\
\text { Corruption }\end{array}$ \\
\hline 13. Labor market & $\begin{array}{l}\text { (1) Restrictive labor regulations }{ }^{\mathrm{f}} ;(2) \text { Inadequately educated workforce }^{\mathrm{f}} \text {; } \\
\text { (3) Poor ethic in national labor force }\end{array}$ \\
\hline
\end{tabular}

a) EBRD (European Bank for Reconstruction and Development) - Economic data, Transition Indicators by country (Data base). Report data from 2006 to 2010.

b) EBRD (European Bank for Reconstruction and Development) - Transition report, 2006; 2007; 2008; 2009; 2010.

c) IMF (International Monetary Fond) - World Economic Outlook Database, April 2011. Report data by the countries from 2006 to 2010 .

d) World Bank - Doing business data base. Report data by the countries from 2006 to 2010 .

e) World Bank - Worldwide Government Indicators, Report data by the countries from 2006 to 2010

f) Schwab et al. $(2008 ; 2009 ; 2010)$ 
included in the analysis, the more reasonable decision will be. But, the inclusion of a large number of factors complicates the analysis. The contribution of this paper lies in the fact that the applied methodology makes it possible to overcome this restriction and facilitate the decision-making process.

\section{DATASET}

The 61 determinants of the business environment are grouped into 13 clusters consisting of a number of indicators that, taken together, indicate the status of a given cluster. Data about these indicators represent their average values in each country in the period from 2006 to 2010 . Table 1 shows the observed clusters, the indicators within them and their data sources.

Indicators within the cluster "closing business" are scaled, taking into consideration the fact that none of the observed indicators for Albania is precisely defined by the law so the in the Doing Business database, instead of proper numerical indicators, there stands the adequate descriptive information for these indicators - that there is no practice. This can be considered as the worst case, so indicators for this country take the greatest value -6 , and other indicators take values of 1-5 depending on the category of defined intervals, given in Table 2, which contains the average value of a given indicator.

\section{METHODOLOGY}

The decision making in case of solving economic problems often is multi-criteria. So, it should be borne in mind that all decision-makers do not evaluate criterions in the same way, or, in other words, they assign them different sets of weights and thus, they form the objective function according to their own preferences. The presence of various criteria means that decisions have been made in conflict conditions and that it is necessary to use more flexible techniques than the strictly mathematical techniques related to the simple optimization (Srdjevic, 2002).

In recent years, it has been developed a large number of methods for decision support in order to facilitate finding out the best compromise solution. One of them is certainly the PROMETHEE method developed by Jean-Pierre Brans and Bertrand Mareschal. This is one of the newest methods in multi-criteria analysis, and is known as one of the most effective and the simplest in this field. The advantages of this method lie in the way of structuring the problem, in the amount of data that can be processed, the possibility of quantifying

Table 2. Scaling the data for cluster "closing business"

\begin{tabular}{|c|c|c|c|}
\hline \multirow{2}{*}{ Value } & \multicolumn{3}{|c|}{ Interval } \\
\cline { 2 - 4 } & $\begin{array}{c}\text { Recovery rate (cents on } \\
\text { the dollar) }\end{array}$ & Time (years) & Cost (\% of estate) \\
\hline 1 & $0-9$ & $0-0.8$ & $0-6$ \\
\hline 2 & $10-18$ & $0.9-1.6$ & $7-12$ \\
\hline 3 & $19-27$ & $1.7-2.4$ & $13-18$ \\
\hline 4 & $28-36$ & $2.5-3.2$ & $25-30$ \\
\hline 5 & $37-45$ & $3.3-4.0$ & no practice \\
\hline 6 & no practice & no practice & \\
\hline
\end{tabular}


qualitative data, good software support and presentation of results (Macharis 2004; I ikolić et al, 2009).

The usage of this method requires defining the appropriate preference function and assigning the weight criteria to each input variable. In the PROMETHEE method it is possible to choose one out of six forms of the preference function (Usual, U-shape; V-shape; Level, Linear, Gaussian) where each form could be described with two thresholds ( $Q$ and $P$ ). The indifference threshold (Q) represents the largest deviation which the decision-maker considers not to be important, while the preference threshold (P) represents the smallest deviation that is considered to be crucial for the decision making. The $\mathrm{P}$ value should not be smaller than Q. The Gaussian threshold (s) is representing the average value of $\mathrm{P}$ and $\mathrm{Q}$ thresholds (Brans,1982; Brans et al., 1984; Brans and Vincke, 1985; Herngren et al., 2006; Vego et al., 2008).

Along with the development of deciding theory and increasing application of computers in all areas of business, there has been developed software that can significantly help decision-makers. The particularly user-friendly software, called Decision Lab, has been developed in collaboration with the Canadian company Visual Decision to assist all sorts of decisionmakers. This software treats matrices similar to that of Table 3, where a1 , a2 ,...ai ,...an are $n$ potential alternatives and $f 1, f 2, \ldots f j$ , ... $\mathrm{fk}$ are $\mathrm{k}$ evaluation criteria. Each evaluation $\mathrm{fj}$ (ai) must be a real number (Brans and Mareschal).
Table 3. The multi-criteria problem set as a matrix

\begin{tabular}{|c|c|}
\hline & $\mathrm{f}_{1}(.) \mathrm{f}_{2}(.) \quad \ldots \ldots \mathrm{f}_{\mathrm{j}}(.) \quad \ldots \ldots \mathrm{f}_{\mathrm{k}}()$. \\
\hline$a_{1}$ & \\
\hline $\begin{array}{l}a_{2} \\
\ldots\end{array}$ & \\
\hline$a_{i}$ & $\mathrm{f}_{\mathrm{j}}\left(\mathrm{a}_{\mathrm{i}}\right)$ \\
\hline$\cdots$ & \\
\hline
\end{tabular}

Each of $\mathrm{n}$ alternatives is characterized by $\mathrm{k}$ criteria, which are chosen depending on the observed problem and the factors influencing the final decision. Criteria differ among themselves, first of all, by the unit of measure and whether this criterion should be maximized or minimized. However, the application of this method eliminates the effects of these differences by means of calculating a single indicator by which the alternatives are ranked - the net flow of preferences $(\varphi)$. I amely, the PROMETHEE method calculates the positive (input) and negative (output) flow of preferences, and on that basis, it is possible to calculate the net flow of preferences as a synthetic indicator of the desirability of an alternative. The positive flow of preference $\left(\varphi^{+}\right)$is expressing how much a certain alternative dominates compared to other alternatives, so if the value is larger $\left(\varphi^{+} \rightarrow 1\right)$, the alternative is more important. The negative flow of preference $(\varphi-)$ is expressing how much a certain alternative is preferred by the other alternatives and the alternative is more important if the value of a negative flow is smaller $(\varphi-\rightarrow 0)$ (Brans and Mareschal, 1994; Albadvi et al., 2007; Anand and Kodali, 2008). In order to calculate these flows, it should be assigned the appropriate weights to each criterion, depending on the preferences of decision makers. 


\section{RESULTS AND DISCUSSION}

Decision Lab is a sophisticated application of the PROMETHEE method. It contains numerous practical accessories that, primarily, provide a full insight into the characteristics of each of the alternatives and the ranking of observed alternatives. To obtain this, it is necessary to assign the preference and indifference threshold and to define whose indicators should be maximized and whose should be minimized. All indicators, except for those from the cluster "closing a business," were awarded a linear function as that these are quantitative data. A threshold of preference is $30 \%$ and the threshold of indifference is $5 \%$. Considering the fact that indicators from cluster "closing business" are scale-out data, then as the preference function for this indicators is taken function Level, the threshold of preference is $10 \%$ and the threshold of indifference is $15 \%$. Also, it should be emphasized that the indicators in direct proportion to FDI inflow are maximized and others, in inversion proportion to FDI inflow, are minimized.

\subsection{Profiles of countries}

Since the Decision Lab provides an insight into the characteristics of each alternative (based on the appropriate graphics), and that, in this case, the alternatives are the observed countries as potential destinations of FDI, with the assistance of this software, it is possible to analyze the characteristics of business environment of each country or, in other words, to create their profiles. In that way, before considering the given scenarios, there should be created a vision of the macroenvironment in these economies, which would be a starting point for further analysis.

In Albania there are many negative aspects of the business environment. The biggest restriction for Albania is the segment that refers to the "closing business" due to the lack of an effective bankruptcy law, that is its weak and selective implementation (European bank for reconstruction and development, 2009). In addition to "closing business", the negative aspect of the business climate in Albania is the policy of the government. Sources of political uncertainty are reflected in the arbitrary change of the regulations (which in some cases are in conflict with other regulations), then, the lack of sanctions for non-compliance, as well as frequent changes of officials who are generally not familiar with current regulations (World bank, 2010). The only cluster all indicators are positive, is the "registering property". The reason for this is that the courts in Albania are not included in the ownership registration. This implies lower number of procedures and therefore less cost and time needed to register the property.

Similar to Albania, Bosnia and Herzegovina has more restrictions than advantages compared to other countries. Especially negative aspects are the insufficient level of privatization, the small and inefficient goods market, the complicated and expensive procedure of registration of ownership and the ineffective government policies. The specific political and constitutional system is a key obstacle for the implementation of necessary reforms. For this reason, in the past few years there has been made insufficient progress in the privatization process. In addition, such situation in the country has influenced the state in goods market. I amely, the market competition was reduced because of the 
dominant participation of Croatian and Serbian products on the market, which had been exempted from customs duties up to September 2009 (European Bank for Reconstruction and Development, 2010). In addition, a significant barrier to potential investors is the registration in the land register, which causes a slow property registration. Only a positive component of the business environment in Bosnia and Herzegovina is the cluster related to the qualitative characteristics of the labor market in this country.

The advantages of the Bulgarian business environment are related to the degree of privatization, the efficiency and size of goods market, the infrastructure development and the government policy. The majority of planned privatizations in Bulgaria were accomplished. The only left privatization to be done are the largest Bulgarian producer of tobacco Bulgartabas, several energy and transportation companies. As part of the EU single market, Bulgarian goods market was largely liberalized, in almost all sectors, which represents a significant advantage of Bulgarian business environment. In addition, the quality of infrastructure is significantly improved, especially in the energy sector (European bank for reconstruction and development, 2010). It should be noted that the situation, regarding the effectiveness of government policy, is much better than in most of the observed countries, but in comparison to other EU members Bulgaria, as Romania, are significantly lagging in this respect.

Positive aspects of the business environment in Croatia are those related to the level of privatization in the country, the efficiency and size of the market goods, the area of taxation and the efficiency of government policy. A significant number of the enterprises was privatized, although there are a number of companies, primarily shipyard whose privatization, in spite of several attempts, failed (European bank for reconstruction and development, 2010). Having completed the final stage of negotiations with the EU, Croatia has implemented many reforms, especially in the field of increasing the level of competition. In addition, significant efforts for reducing the informal economy have led to tax cuts, and also to their easy payment. As a result, Croatia has achieved a significant advantage in this area compared to other observed countries. Another area which has undergone many reforms is the efficiency of government policies. The aim of these reforms is, above all, a compliance with the practice that applies in the EU. The Croatian authorities have made a significant progress in this field, but the European Commission considers that there is still more space for improvement, in terms of the public administration reform, the increased judicial independence and the fight against corruption (European Commission, 2010). The important limitation of the Croatian business environment is a segment of foreign trade, which has also been improved for many years, in the sense of the simplification of regulations in this field.

A positive aspect of the Macedonian business environment is a relatively high level of privatization. By 2009, a large number of state-owned enterprises has been privatized. After that, the privatization process has been slowed to some extent since the privatization of remaining long-term loss-making state-owned enterprises was not possible due to the lack of interest for them (European bank for reconstruction and development, 2010). A significant restriction of this country is the state of the labor 
market. This refers primarily to the significant gap between supply and demand for the labor force, in terms of an inadequate qualification structure (it is significantly influenced the level of unemployment in this country). This problem can be solved by the educational reform. In addition, considerable effort has been made to improve of the labor legislation, but it is not yet in accordance with European standards.

I egative aspects of the Montenegro business environment are the insufficient degree of privatization and the state in labor market. The majority of state-owned firms, primarily from the financial sector, have been privatized, but the big companies in the field of transport and energy are still waiting for its owner. In addition, the authorities of this country usually tend to keep certain parts of shares in the privatized companies, and it also leads to be re-nationalization of certain companies, which also slows down the process of privatization in this country. The flexibility of the labor market in Montenegro is still not satisfactory despite the fact that numerous reforms have been implemented. The Labor Law of 2008 contains a number of protectionist clauses that further discourage creation of new jobs.

The Romanian economy offers many advantages to foreign investors: the efficient and large market goods, the developed infrastructure, many benefits for starting a business and easy getting the construction permits and the effective government policy. Romania has implemented many reforms to improve efficiency of the goods market, in order to become a member of the single European market. A significant advantage of the Romanian market is that it is the second largest in South East Europe (just after Poland). The infrastructure in this country is more developed than in other observed countries in the region, but it is although still below European standards. Therefore, to start a business is fairly easier, especially in the segment of getting building permits. As for adopting the Strategy for fighting corruption, Romania has made a significant progress in terms of strengthening the rule of law, judicial reform and fighting corruption.

The greatest restrictions to foreign investors in Serbia are the low level of privatization, the unfavorable macroeconomic stability and the ineffectiveness of government policy, while the only positive segment is the state in labor market. The transition in Serbia has started later than in most other countries, and over the past ten years it has been trying to catch up with other countries. However, major structural changes are just ahead. The privatization of large enterprises, especially in the energy and telecom sector, has not yet completed (European bank for reconstruction and development, 2010). State-owned companies, that operate with the loss, burden the state budget that significantly affects the macroeconomic stability of the country. The Serbian economy is characterized by high inflation and unemployment, as well as significant increase of the country's public debt to GDP. Due to the slowdown of economic activity and the lack of progress in the implementation of the privatization process, a substantial part of skilled workforce is unemployed, despite the relatively flexible labor legislation.

\subsection{PROMETHEE II complete ranking of countries}

Taking into account the fact that some determinants of the business environment might be of special importance to investors, 


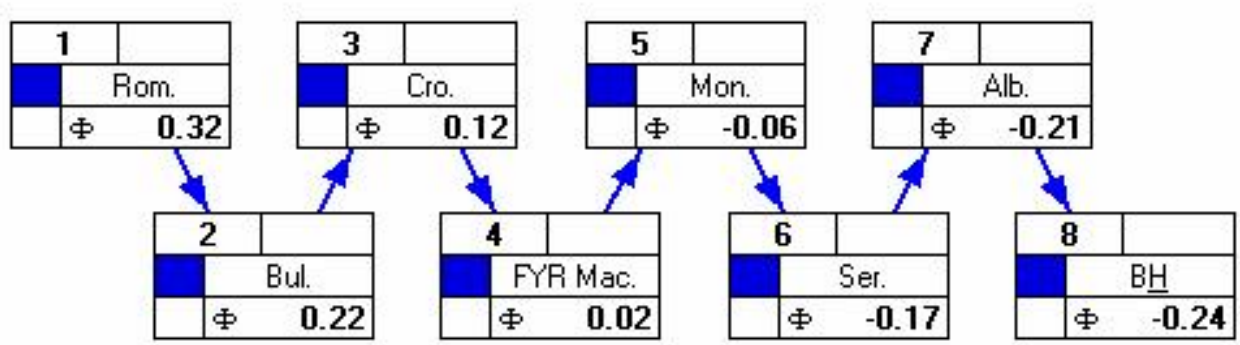

Figure 1. PROMETHEE II complete ranking of alternatives (countries) in the absence of preferences

using the PROMETHEE method several different scenarios can be analyzed, depending on the preferences of investors. This paper considers three different scenarios. Firstly, there has been analyzed the one which assumes that the investor does not prefer any of the segments of the business environment and the weights of all the considered indicators are equal (Scenario 1). The other two scenarios imply the existence of certain preferences of investors. In order to take into account the preferences in decision-making, firstly, the corresponding weight has been initially assigned to each cluster, and then to each indicator. Depending on the preferences of investors the following two scenarios have been analyzed:

1. When investors prefer large and efficient goods market in the country (Scenario 2),

2. When investors prefer countries with the favorable macroeconomic stability (Scenario 3).

5.2.1. Ranking of countries in the absence of preferences (Scenario 1)

As an initial scenario that was considered a case where investors do not prefer any of the segment of the business environment in order to determine the order of countries and differences between them in this general scenario. In order to achieve this, each of the 61 indicators from Table 1 was assigned the same weight $100: 61=1.64 \%$. By using the PROMETHEE method there was performed the ranking of countries by the best to the worst alternative, depending on the state business environment in them. The obtained results are shown on Figure 1.

The figure 1 indicates that the top-ranked are Romania and Bulgaria, and the worst ranked are Albania and Bosnia and Herzegovina. It should also be noticed that the positive net flows, apart from Romania and Bulgaria, have Croatia and Macedonia too, and that there are large differences between the net flows of preferences for these four countries, so we can conclude that the business environment in these countries is significantly different.

\subsubsection{Ranking of countries when} investors prefer large and efficient goods market in the country (Scenario 2)

The Scenario 2 takes into account the fact that the investor's preferences regarding goods market in the country as a potential destination of FDI. Considering these preferences of investors, authors were assigned weights to observe clusters and indicators within them as it is shown in Table 4. 
Table 4. Weights of business environment clusters and indicators within them in the case where investors prefer large and efficient goods market in the country

\begin{tabular}{|l|c|c|}
\hline \multicolumn{1}{|c|}{ CLUSTER } & $\begin{array}{c}\text { CLUSTER } \\
\text { WEIGHT } \\
(\%)\end{array}$ & $\begin{array}{c}\text { WEIGHT OF I!̣ICATORS } \\
\text { WITHI! CLUSTER (\%) }\end{array}$ \\
\hline 1. Level of privatization & 7 & $(20,10,40,20)$ \\
\hline 2. Efficiency and size of good market & 30 & $(40,10,20,18,12)$ \\
\hline 3. Development of financial market & 7 & $(30,10,20,10,15,15)$ \\
\hline 4. Infrastructure & 5 & $(20,20,20,20,20)$ \\
\hline 5. Macroeconomic stability & 9 & $(50,30,20)$ \\
\hline $\begin{array}{l}\text { 6. Starting a business and dealing with } \\
\text { construction permits }\end{array}$ & 5 & $(10,5,5,30,20,15,15)$ \\
\hline 7. Registering Property & 5 & $(50,20,30)$ \\
\hline $\begin{array}{l}\text { 8. Protecting investors and enforcing } \\
\text { contracts }\end{array}$ & 5 & $(20,5,15,40,10,5,5)$ \\
\hline 9. Paying taxes & 7 & $(10,30,60)$ \\
\hline 10. Trading across borders & 5 & $(10,10,30,10,10,30)$ \\
\hline 11. Closing a business & 5 & $(30,20,50)$ \\
\hline 12. Governance indicators & 5 & $(15,15,15,15,20)$ \\
\hline 13. Labor market & 5 & $(20,50,30)$ \\
\hline & $\sum=100$ & \\
\hline
\end{tabular}

As it can be seen from Table 4, the cluster "efficiency and size of the market goods" was assigned the highest weight of $30 \%$ in order to highlight the importance of this cluster to the investor. To other clusters there were assigned weights depending on their relative importance in case of existence of such preferences. Then, in accordance with that, the weights were determined for each indicator too, which sum within each cluster is in the amount of $100 \%$. The Decision Lab software package requires the allocation of the weight coefficient for each indicator, and in order to take into account both weights for the cluster and for indicators, each indicator was assigned a weight obtained by multiplying the weight of the cluster and the given indicator from that cluster. In accordance with that, the PROMETHEE method was determined the order of countries as it is shown on Figure 2.

On the basis of obtained results from Figure 2, it can be concluded that the topranked are Romania, Croatia and Bulgaria.

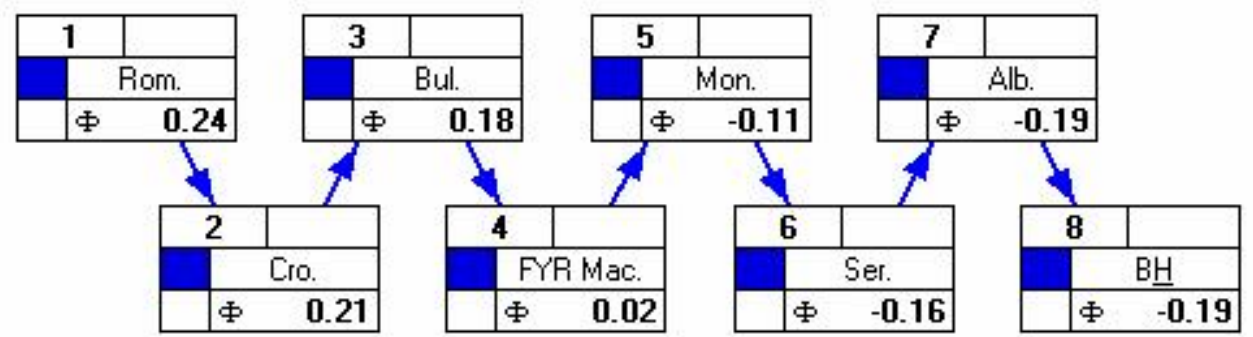

Figure 2. PROMETHEE II complete ranking of alternatives (countries) when investors prefer large and efficient good market in the country 
At the same time, the difference between their net preferences flows was significantly reduced than it was the general case. The worst ranked are Albania and Bosnia and Herzegovina whose markets are not the smallest among observed countries but they are characterized by significant inefficiencies, which greatly affects their position.

\subsubsection{Ranking of countries where the} investor prefers a favorable macroeconomic stability (Scenario 3)

The macroeconomic stability in the country can be of great importance for investors, since it implies relatively stable business conditions. For this reason, this scenario was taken into consideration. The cluster "macroeconomic stability" it was assigned weight of $30 \%$. Allocation of clusters weights and indicators within them is given in Table 5 .
The figure 3 shows the order of countries, obtained on the basis of such allocation of weights and by using the PROMETHEE method.

The results from the Figure 3, indicate that the top-ranked are Romania and Croatia. Thereby, differences in net flows of preferences between these two countries are very small, indicating that these countries in this aspect do not differ significantly. In addition to these countries, Macedonia and Bulgaria have a positive net flow of preferences but on significantly less level than the best ranked countries. Obviously, the worst-ranked country in this case is Serbia, indicating that the macro-economic stability in this country is a significant constraint for foreign investors.

Table 5. Weights of business environment clusters and indicators within them in the case when investor prefers a favorable macroeconomic stability

\begin{tabular}{|c|c|c|}
\hline CLUSTER & $\begin{array}{c}\text { CLUSTER } \\
\text { WEIGHT (\%) }\end{array}$ & $\begin{array}{c}\text { WEIGHT OF } \\
\text { I!DICATORS WITHI! } \\
\text { CLUSTER }(\%)\end{array}$ \\
\hline 1. Level of privatization & 7 & $(20,10,40,20)$ \\
\hline 2. Efficiency and size of good market & 7 & $(40,10,20,18,12)$ \\
\hline 3. Development of financial market & 5 & $(40,15,20,5,10,10)$ \\
\hline 4. Infrastructure & 5 & $(20,20,20,20,20)$ \\
\hline 5. Macroeconomic stability & 30 & $(60,30,10)$ \\
\hline $\begin{array}{l}\text { 6. Starting a business and dealing with } \\
\text { construction permits }\end{array}$ & 5 & $(10,5,5,30,20,15,15)$ \\
\hline 7. Registering Property & 5 & $(50,20,30)$ \\
\hline $\begin{array}{l}\text { 8. Protecting investors and enforcing } \\
\text { contracts }\end{array}$ & 5 & $(20,5,15,40,10,5,5)$ \\
\hline 9. Paying taxes & 7 & $(10,30,60)$ \\
\hline 10. Trading across borders & 7 & $(10,10,30,10,10,30)$ \\
\hline 11. Closing a business & 5 & $(30,20,50)$ \\
\hline 12. Governance indicators & 7 & $(15,20,15,15,15,20)$ \\
\hline 13. Labor market & 5 & $(20,50,30)$ \\
\hline
\end{tabular}




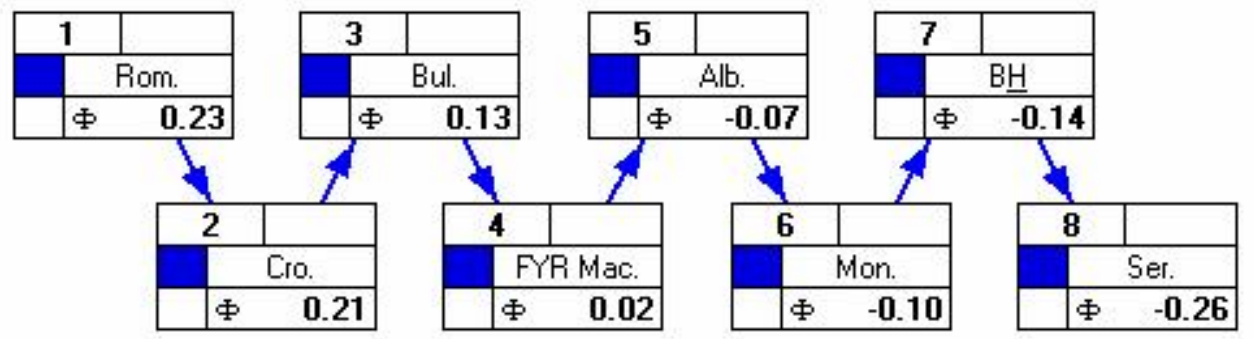

Figure 3. PROMETHEE II complete ranking of alternatives (countries) when the investor prefers a favorable macroeconomic stability

\section{CONCLUSION}

In the context of expressed globalization and integration processes, the foreign direct investment is a key factor of economic growth and development for a country in transition, as well as the main instrument of its transformation to market economies. Considering the importance of FDI in transition countries, governments of these countries need to lead an active policy of attracting FDI, which would be incorporated into the national development strategy. This implies the implementation of many institutional, political, economic and other necessary reforms, in order to create a favorable business environment as the main instrument of the competitive struggle of transition countries in attracting FDI.

The business environment as a multidimensional phenomenon involves numerous components and most of them are endogenous. Considering numerous aspects of business environment, the process of decision-making about the allocation FDI requires the application some multi-criteria methods of analysis for the sake of comparing the considered alternatives. One of the most commonly used multi-criteria methods of analysis is the PROMETHEE method, that provides ranking of the observed countries, deriving a number of different indicators into a single indicator - the net flow of preferences. The software package Decision Lab is a useful tool that allows easy of the application PROMETHE methods. The application of this software package can greatly facilitate the investors to make a decision about the allocation of FDI.

While considering given scenarios, the three groups of countries can be separated. The first group includes Romania, Bulgaria and Croatia, which have implemented numerous reforms that undoubtedly contributed to regulation of business environment, and on this way, these countries gained a significant advantage compared to other observed countries. Most of these reforms were driven by tendency to integrate into the EU, which can be joined by the countries that have reached the required standards. I amely, Romania, besides to much larger markets, also provides many other benefits to foreign investors for starting and conducting business, which significantly could affect the position of this country in the considered scenarios.

The second group consists of Macedonia and Montenegro, which takes up the fourth and the fifth position in all scenarios. Macedonia in some scenarios had a positive net flow of preferences, but it was much lower than those who had top-ranked alternatives, indicating that these countries have made some progress in terms of the arrangement of business environment, but it 
is still insufficient to provide a greater inflow of foreign capital.

The third group of countries includes Serbia, Albania and Bosnia and Herzegovina, which in all scenarios takes up one of the last three places. Ahead of these countries there is a period of significant economic, institutional, structural and other reforms necessary to create a favorable and stable business environment, leading to a greater inflow of FDI.

Future studies in this field may need to expand the number of countries and to perform the ranking of the countries on basis of some more objective criterion, since the distribution of weight in this paper is determined on the basis of subjective assessment of the author.

\section{Acknowledgements}

The authors feel indebted to the company Visual Decision Inc. Montreal, Canada, for software package Decision Lab 2000 provided to them free of charge.

This paper is a part of research project I $\mathrm{o}$. 179015 (Challenges and prospects of structural changes in Serbia: Strategic directions for economic development and harmonization with EU requirements), financed by the Ministry of Science and Technological Development of the Republic of Serbia.

\section{References}

Beslać M. (2006). The scope of foreign direct investment in South Eastern Europe and the economy of SCG. Economic annals, 168(14): 95-108.

Bevan A., Estrin S. (2004). The determinants of foreign direct investment into European transition economies. Journal of Comparative Economics, 32(4): 775-787.

Birsan, M., Buiga, A. (2009). FDI

Determinants: Case of Romania. Transit Stud Rev, 15: 726-736.

Brans, J. P., Mareschal, B., How to Decide with PROMETHEE. http://homepages.ulb.ac.be/ bmaresc/Prom Web.htm Accessed on August 232011.

Brans, J.P. (1982). 'L'ingéniérie de la decision; Elaboration d'instruments d'aide à la décision. Méthode PROMETHEE', In R. I adeau and M. Landry, editors, L'aide ŕ la décision: I ature, Instruments et Perspectives d'Avenir. Presses de l'Université Laval. Québec, Canada, pp. 183-213.

Brans, J.P. Mareschal, B. Vincke, Ph. (1984). PROMETHEE: A new family of outranking methods in multi-criteria analysis, in Brans, J.P. (Ed.), Operational Research '84, I orth-Holland, Amsterdam, pp. 447-490.

Brans, J.P., Vincke, Ph. (1985). A preference ranking organisation method: The PROMETHEE method for MCDM. Management Science, 31(6): 647-656.

Büthe T., Milner V. H. (2008). The politics of foreign direct investment into developing countries: Increasing FDI through international trade agreements?. American Journal of Political Science, 52 (4):741-762.

Carstensen, K., Toubal, F. (2004). Foreign direct investment in Central and Eastern European countries: a dynamic panel analysis. Journal of Comparative Economics, 32: 3-22.

Doing business database, http://www.doingbusiness.org/data Accessed on May 232010

Donor Committee for Enterprise Development, (2008) Supporting business environment reforms. Practical guidance for development 
http://rru.worldbank.org/documents/DonorG uidance.pdf Accessed on May 302011.

EBRD (European bank for reconstruction and development), (2006). Transition report 2006: Finance in transition, London, ISB! : 978-1-898802-28-9.

EBRD (European bank for reconstruction and development), (2007). Transition report 2007: People in transition, London, ISBI : 978-1-898802-29-7.

EBRD (European bank for reconstruction and development), (2008). Transition report 2008, Growth in transition, London, ISBI : 978-1-898802-31-0.

EBRD (European bank for reconstruction and development), (2009). Transition report 2009, Transition in crisis?, London, ISB! : 978-1-898802-33-4.

EBRD (European bank for reconstruction and development), (2010). Transition report 2010, Recovery and reform, London, ISBI : 978-1-898802-33-1.

EBRD (European bank for reconstruction and development). Economic data, Transition indicators by country (Data base) http://www.ebrd.com/pages/research/econo mics/data/macro.shtml\#ti Accessed on May 252011.

European commission, (2010). Croatia 2010 progress report, Commission staff working document, Brussels, 09 I ovember 2010.

Herngren, L., Goonetilleke, A., Ayoko, G. A. (2006). Analysis of heavy metals in roaddeposited sediments. Analytica Chimica Acta, 571(2): 270-278.

IMF (International Monetary Fond), World Economic Outlook Database, April 2 http://www.imf.org/external/pubs/ft/weo/20 11/01/weodata/weoselgr.aspx\#g901, Accessed on May 252011.

Kalotay K., Sulstarova A. (2010).
Modeling Russian outward FDI. Journal of International Management, 16(2): 131-142

Macharis, C., Springael, J., De Brucker, K., Verbeke, A. (2004). PROMETHEE and AHP: The design oh operational synergies in multicriteria analysis. Strengthening PROMETHEE with ideas of AHP. European Journal of Operational Research, 153(2): 307-317.

I ikolić, Dj., Jovanović, I., Mihajlović, I., Živković, Ž. (2009). Multi-criteria ranking of copper concentrates according to their quality - An element of environmental management in the vicinity of copper Smelting complex in Bor, Serbia, Journal of Environmental Management, 91: 509-515.

Rasciute S., Pentecost E. (2010). A I ested logit approach to modelling the location of foreign direct investment in the Central and Eastern European Countries. Economic Modelling, 27(1): 32-39

Schwab, K., Martin, X.S., Greenhill R. (2009). The global competitiveness report 2009-2010.World economic forum, ISBI! : 978-92-95044-25-8

Schwab, K., Martin, X.S., Greenhill R. (2010). The global competitiveness report 2010-2011. World economic forum; ISBI : 978-92-95044-87-6.

Schwab, K., Martin, X.S., Paua F. (2008). The global competitiveness report 20082009, World economic forum; ISBI : 97892-95044-11-1.

Srdjevic B., 2002. Evaluation of storage reservoir purposes by means of multicriteria optimization models. Water management, 34(1-6): 35-45.

Tatoglu E., Glaister K. (2010). An analysis of motives for western FDI in Turkey. International Business Review, 7(2): 203-230.

The International Bank for Reconstruction and Development, The 
World Bank, (2008). Doing business in South East Europe in 2008 h $\mathrm{t} t \mathrm{p}: / / \mathrm{w} w \mathrm{w}$. $\mathrm{s}$ e $\mathrm{r}$ b i a business.com/serb/images/stories/pdfs/Evro pska_Unija_izvoz/poslovanje_u_SEE.pdf Accessed on July 292011

Trevino J. L., Thomas E. D., Cullen J. (2008). The three pillars of institutional theory and FDI in Latin America: An institutionalization process. International Business Review, 17(1): 118-133.

Vego, G., Kučar-Dragičević, S., Koprivanac, I . (2008). Application of multicriteria decision-making on strategic municipal solid waste management in Dalmatia, Croatia. Waste Management 28(11): 2192-2201.

World bank, (2010). Albania: The new growth agenda. A country economic memorandum, http://wwwwds.worldbank.org/external/default/WDSCo ntentServer/WDSP/IB/2010/11/21/0003330 37 20101121235513/Rendered/PDF/53599 0ESW0gr

World Bank, International Finance Corporation, 2010, Doing business 2011: making difference for entrepreneurs, http://www.doingbusiness.org/ /media/fpdk $\mathrm{m} /$ doing 20 business/documents/annualreports/english/db11-fullreport.pdf Accessed on May 252011

Worldwide governance indicators, http:// data.worldbank.org/data catalog/worldwide-governance-indicators, Accessed on June 12011.

\title{
АНАЛИЗА ПОСЛОВНОГ ОКРУЖЕЊА ПРИМЕНОМ МУЛТИКРИТЕРИЈУМСКЕ АНАЛИЗЕ - ПРИМЕР ТРАНЗИЦИОНИХ ПРИВРЕДА НА БАЛКАНУ
}

\author{
Саша Обрадовић ${ }^{a}$, Александра Федајев ${ }^{b^{*}}$, Ђорђе Николић \\ а Универзитет у Крагујевиу, Економски факултет, \\ Буре Пуияара Старог 3, Крагујеваи, Србија \\ $b$ Универзитет у Београду, Технички факултет у Бору, \\ Војске Југославије 12, Бор, Србија
}

\section{Извод}

За земље у транзицији, с обзиром да немају довољно сопствених финансијских средстава, привлачење страних директних инвестиција представља основни услов за повећање производње и запослености, како би обезбедиле дугорочно одржив привредни раст. Поред тога, стране директне инвестиције представљају битан инструмент преструктурирања ових привреда на тржишним принципима и начелима. Међутим остваривање овог циља није нимало једноставно. Како би земље у транзицији привукле стране инвеститоре, неопходно је да креирају повољан пословни амбијент, што захтева бројне економске, институционалне, политичке и друге реформе. Циљ овог рада јесте да укаже на најважније факторе привлачења страних директних инвестиција и да применом мултикритеријумске анализе изврши рангирање транзиционих привреда на Балкану у зависности од преференција инвеститоракоје се односе на поједине компоненте пословног окружења.

Кључне речи: Стране директне инвестиције, пословно окружење, мултикритеријумска анализа, PROMETHEЕ метода. 